Article

\title{
Seed Germination in Cistus ladanifer: Heat Shock, Physical Dormancy, Soil Temperatures and Significance to Natural Regeneration
}

\author{
Luís Silva Dias ${ }^{1, *(D)}$, Isabel Pires Pereira ${ }^{1,2,+}$ and Alexandra Soveral Dias ${ }^{1}$ \\ 1 Department of Biology, University of Évora, Ap. 94, 7000-554 Évora, Portugal; ipp@uevora.pt (I.P.P.); \\ alxandra@uevora.pt (A.S.D.) \\ 2 Institute of Mediterranean Agricultural and Environmental Sciences, University of Évora, Ap. 94, 7000-554 \\ Évora, Portugal \\ * Correspondence: 1sdias@uevora.pt; Tel.: +351-266-760-881 \\ + Deceased 12 May 2016.
}

Received: 21 December 2018; Accepted: 7 March 2019; Published: 12 March 2019

\begin{abstract}
Seeds of Cistus ladanifer experience bursts of germination following fires. The effects of heat shock from $10{ }^{\circ} \mathrm{C}$ to $150{ }^{\circ} \mathrm{C}$ on seed germination were investigated by final germination plus the number of days required for germination to start and finish, and symmetry of cumulative germination. The occurrence of physical dormancy in C. ladanifer seeds was investigated by a variety of methods, including imbibition, scanning electron microscopy (SEM) and light microscopy, and use of dyes. The significance of responses of $C$. ladanifer seeds to fires was investigated essentially by abstracting existing literature and by using fire effects models and simulations. Parameters of germination were variously affected by heat treatments-positively in the range $80-100{ }^{\circ} \mathrm{C}$, negatively above $130{ }^{\circ} \mathrm{C}$. Non-dormancy was consistently found in about $30 \%$ of seeds but no evidence was obtained to support the existence of physical dormancy in the dormant fraction of $C$. ladanifer seeds. Two complementary processes seem to be in place in seeds response to fire. A direct fire-driven increase in germination of virtually all seeds in response to the appropriate heat load produced by fire or, in the absence of such heat loads, the germination of the non-dormant fraction provided that above-ground vegetation burns.
\end{abstract}

Keywords: Cistus ladanifer; fire effects; heat shock; imbibition; physical dormancy; seed coat; seed germination; soil temperatures

\section{Introduction}

Mediterranean-type ecosystems are fire-prone habitats where a large number of species have seed germination stimulated directly or indirectly by fires, but either way the general result is the induction of massive germination of largely dormant or quiescent soil seedbanks, especially of annuals and shrubby perennials [1]. Cistus ladanifer (Cistaceae) and other Cistus are some of those shrubby perennials that show dramatic increases of germination following fires [2-4].

Portugal and Spain are the main areas of distribution of $C$. ladanifer, which is also cultivated and highly appreciated as ornamental elsewhere $[5,6]$. This species occupies large areas, frequently as pure stands which are viewed as advanced stages of sclerophyllous forests degradation [7]. It is a pioneer species that slows or almost stops successions. Its spreading is strongly enhanced by field abandon from cultivation, overgrazing and fire $[8,9]$, and reports of its possible classification as invasive species in South Africa appeared recently [10].

Along with other Cistus it is an obligate seeder [2,11-13] with small seeds. Seeds of $C$. ladanifer are held inside capsules and usually are very numerous, globose-polyhedric [14]. Their seed coats 
are made of an outer waxy layer, followed by palisade cells with strongly lignified cell walls. Between the palisade cells and the endosperm one or more layers of slightly differentiated cells occur. The endosperm is well developed, rich in starch and completely surrounds the embryo [15].

In the 1950s and early 1960s the usefulness of several Cistus to control erosion and replace native species less resistant to fires or faster burners was investigated in Southern California [11,16-18], which might explain the occurrence of Cistus in a number of Californian counties nowadays [19]. C. ladanifer was found to be the most flammable Cistus investigated [11]. However, in general Cistus appear to be much less flammable [20] than has been stated before [21].

Nevertheless, laboratory and field studies have shown that heat alone can induce very high percentages of germination in C. ladanifer [11,12,22-26]. In general only a relative small range of temperatures have been tested and attention was only paid to final germination. Thus it is unknown whether and how heat shock affects other important aspects of germination like the time needed to its start or the time needed afterwards to its completion.

The most frequent explanation for the direct effects of fire on germination of $C$. ladanifer and other Cistus is that heat shock causes the rupture of seed coats allowing water to reach embryos $[4,22,25,27,28]$. This explanation is based upon the assumption that seeds of $C$. ladanifer and other Cistus possess physical dormancy, their seed coats being impermeable to water $[29,30]$. However, a screen of literature fails to show experimental support to the assumption that $C$. ladanifer seed coat is a physical barrier to water uptake by seeds.

This study aimed to investigate three main questions. (1) What are the effects of heat shock on germination of $C$. ladanifer seeds evaluated across a wide range of heat shock temperatures not only by final germination but also by time required for germination to start and to finish, and by the shape of cumulative germination over time? (2) Is there evidence that the response of $C$. ladanifer seed germination to heat shock results from increased water uptake due to mechanical fracture of seed coat? (3) Given soil temperatures during fires what might be the ecological significance of seed responses to heat shock to the renewal of $C$. ladanifer stands?

\section{Results}

\subsection{Experiment 1: Effects of Temperature and Light Regime on Final Seed Germination of Cistus ladanifer}

Data of final germination of the two sets of seeds incubated in two different occasions under light and constant $20^{\circ} \mathrm{C}$ were compared, found not significantly different $\left(t_{6}=0.12, P=0.912\right)$, and pooled. Final germination ranged from $21.6 \pm 5.0 \%$ to $37.9 \pm 7.6 \%$, at constant $30^{\circ} \mathrm{C}$ and $15{ }^{\circ} \mathrm{C}$ respectively, both with photoperiod (Table S1). Homoscedasticity among samples was present and no significant differences were found among the final germination of treatments with photoperiod, regardless of seeds being incubated under constant or alternate temperatures $\left(F_{7,28}=1.58, P=0.182\right)$, neither between constant and alternate temperatures $\left(t_{34}=1.12, P=0.269\right)$, nor between light and dark treatments $\left(t_{10}=0.28, P=0.788\right)$.

\subsection{Experiment 2: Effects of Heat Shock on Seed Germination of Cistus ladanifer}

Parameters fitted for the relationship between heat shock lasting $15 \mathrm{~min}$ and final germination using Equation (4) were $x=-48.031, z=0.395$ for the segment $10-70{ }^{\circ} \mathrm{C} ; x=-22.596, z=2.637$ for the segment $70-90{ }^{\circ} \mathrm{C} ; x=24.998, z=2.592$ for the segment $90-140{ }^{\circ} \mathrm{C}$ but data for the $130{ }^{\circ} \mathrm{C}$ treatment had to be omitted from the regression analysis. $R^{2}$-values were $0.777, \approx 1$, and 0.985 respectively. All predicted mean values of final germination lied within the $95 \%$ confidence intervals of observed means. Combining the tree models (overall $R^{2}=0.960$ ) final germination increased slowly with heat treatments (Figure 1a and Table S2) from the $10{ }^{\circ} \mathrm{C}$ treatment $(31.7 \pm 5.0 \%)$ to the $70{ }^{\circ} \mathrm{C}$ treatment $(48.4 \pm 6.9 \%)$. From then on the response was more intense, with all seeds germinating in the $90{ }^{\circ} \mathrm{C}$ treatment. For higher temperatures, final germination decreased until the $120^{\circ} \mathrm{C}$ treatment $(26.3 \pm 1.4 \%)$. No germination was recorded in $140{ }^{\circ} \mathrm{C}$ and $150{ }^{\circ} \mathrm{C}$ treatments. Seeds of these two 
treatments and nongerminated seeds treated with $120{ }^{\circ} \mathrm{C}$ and $130{ }^{\circ} \mathrm{C}$ were preyed by microbes and rotted.

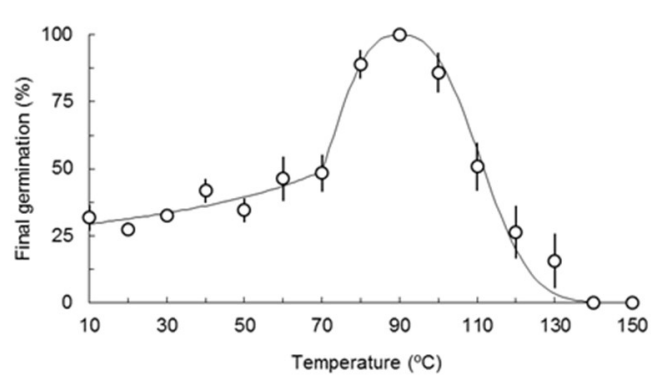

(a)

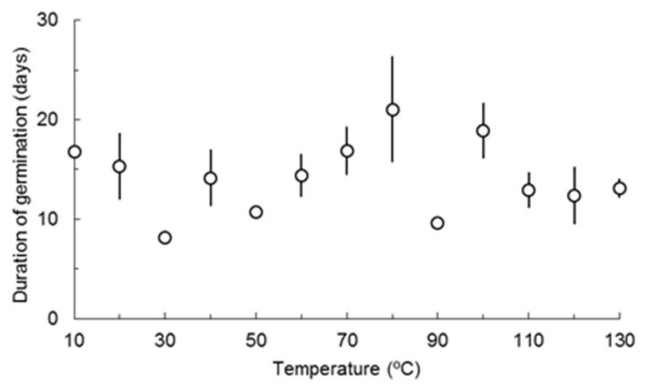

(c)

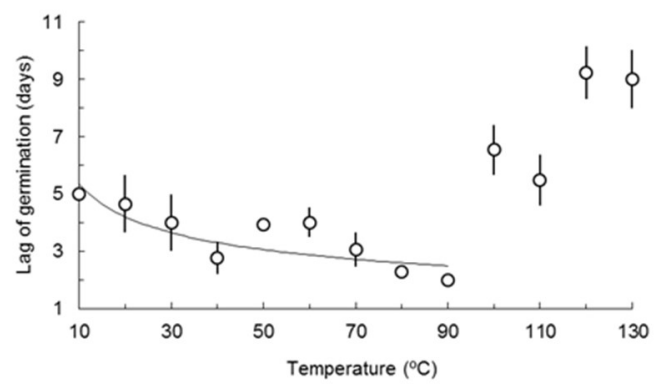

(b)

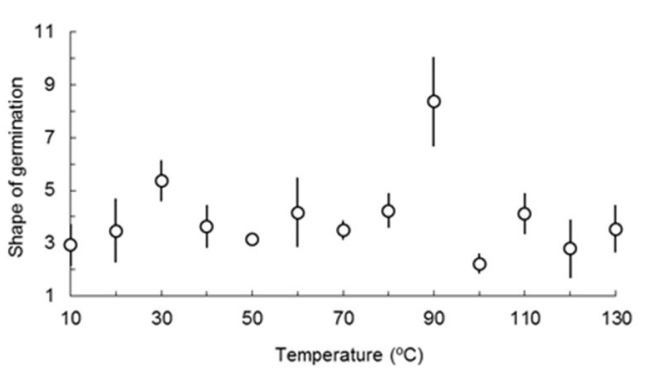

(d)

Figure 1. Response of seed germination of Cistus ladanifer to heat treatments lasting 15 min: (a) final germination; (b) time needed for the start of germination (lag); (c) time needed to the completion of germination minus the lag of germination (duration); (d) shape of germination. Circles for observed values, line for expected values; vertical bars for standard errors (SE).

The three-term Weibull equation (Equation (3)) could be fitted to cumulative germination over time in 53 replicates, including at least two in every heat treatment (Table S2). $R^{2}$ ranged between 0.167 and $\approx 1$ (mean $0.828 \pm 0.027$ ). Regressing parameters of Weibull equation, including derived ones, to heat treatments was only achieved in lag of germination.

Lag of germination $l$ ranged from $2.0 \pm 0.03$ days at $90{ }^{\circ} \mathrm{C}$ to $9.2 \pm 0.9$ days at $120{ }^{\circ} \mathrm{C}$ (Figure $1 \mathrm{~b}$ and Table S2). The power law (Equation (2)) fitted to the descending segment of $l$ was highly significant $\left(F_{1,36}=10.84, P=0.002, R^{2}=0.583\right.$, lack of fit with $\left.F_{7,29}=1.14, P=0.366\right)$. Fitted parameters were $a=11.960$ and $b=0.349$. All predicted mean values of germination lied within the $95 \%$ confidence intervals of observed means except for heat treatments $10{ }^{\circ} \mathrm{C}$ and $50{ }^{\circ} \mathrm{C}$.

Parallel to the dose-response approach used with final germination and lag of germination, point estimates of all parameters for $10{ }^{\circ} \mathrm{C}$ to $130{ }^{\circ} \mathrm{C}$ treatments were compared. Results for homocedasticity tests, maximum likelihood estimates of Box-Cox transformations, and simultaneous comparisons of means are summarized in Appendix A.

Significant differences were found among final germination of seeds treated with $80^{\circ} \mathrm{C}, 90^{\circ} \mathrm{C}$, $100{ }^{\circ} \mathrm{C}$ and $130{ }^{\circ} \mathrm{C}$ and all others which did not differ among them (pooled mean of the former $38.7 \pm 2.6 \%$ ). Also, no significant differences were found $\left(t_{6}=0.34, P=0.742\right)$ between final germination of seeds treated with $80^{\circ} \mathrm{C}$ and $100{ }^{\circ} \mathrm{C}$ (pooled mean $87.4 \pm 4.4 \%$ ).

Significant differences were found among lag of germination of seeds treated with $40{ }^{\circ} \mathrm{C}, 70^{\circ} \mathrm{C}$, $80^{\circ} \mathrm{C}$ and $90^{\circ} \mathrm{C}$, which did not differ among them (pooled mean $2.6 \pm 0.3$ days) and all others which did not differ among them also (pooled mean $5.5 \pm 0.4$ days).

The number of days necessary to attain final germination minus the number of days required to its beginning $\left(D_{100}\right)$ ranged from $8.1 \pm 0.7$ days at $30^{\circ} \mathrm{C}$, closely followed by $90{ }^{\circ} \mathrm{C}(9.6 \pm 0.2$ days $)$ 
to $21.0 \pm 5.3$ days at $80^{\circ} \mathrm{C}$ (Figure $1 \mathrm{c}$ and Table S2) with heat treatment $90^{\circ} \mathrm{C}$ breaking the trend for an oscillatory behavior of $D_{100}$. Significant differences were found among $D_{100}$ of seeds treated with $30^{\circ} \mathrm{C}$ and all others which did not differ among them (pooled mean $14.8 \pm 0.9$ days).

Shape of germination $c$ ranged from $2.2 \pm 0.4$ at $100{ }^{\circ} \mathrm{C}$ to $8.4 \pm 1.7$ at $90{ }^{\circ} \mathrm{C}$ (Figure $1 \mathrm{~d}$ and Table S2). Significant differences were found among $c$ of seeds treated with $90{ }^{\circ} \mathrm{C}$ and all others which did not differ among them (pooled mean $3.7 \pm 0.3$ ).

Pairwise variation of final germination, lag of germination, and duration of germination is plotted in Figure 2 and shows an inverse variation of final germination and lag of germination (Figure 2a), a tendency for a direct variation of final germination and duration of germination (Figure $2 b$ ), which essentially results in no common variation, either inverse or direct between lag and duration of germination (Figure 2c).

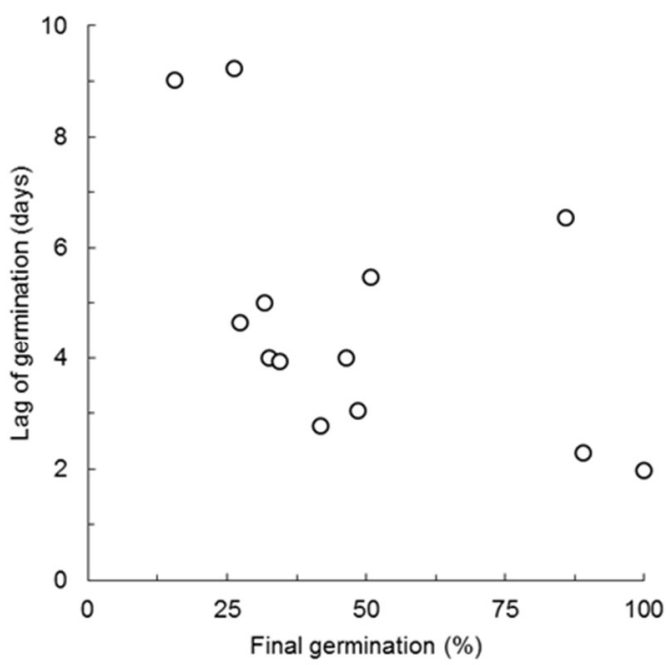

(a)

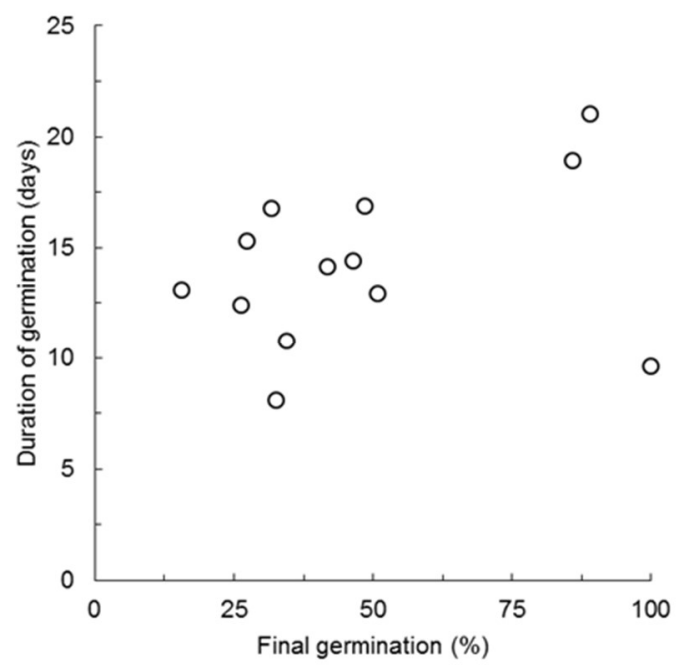

(b)

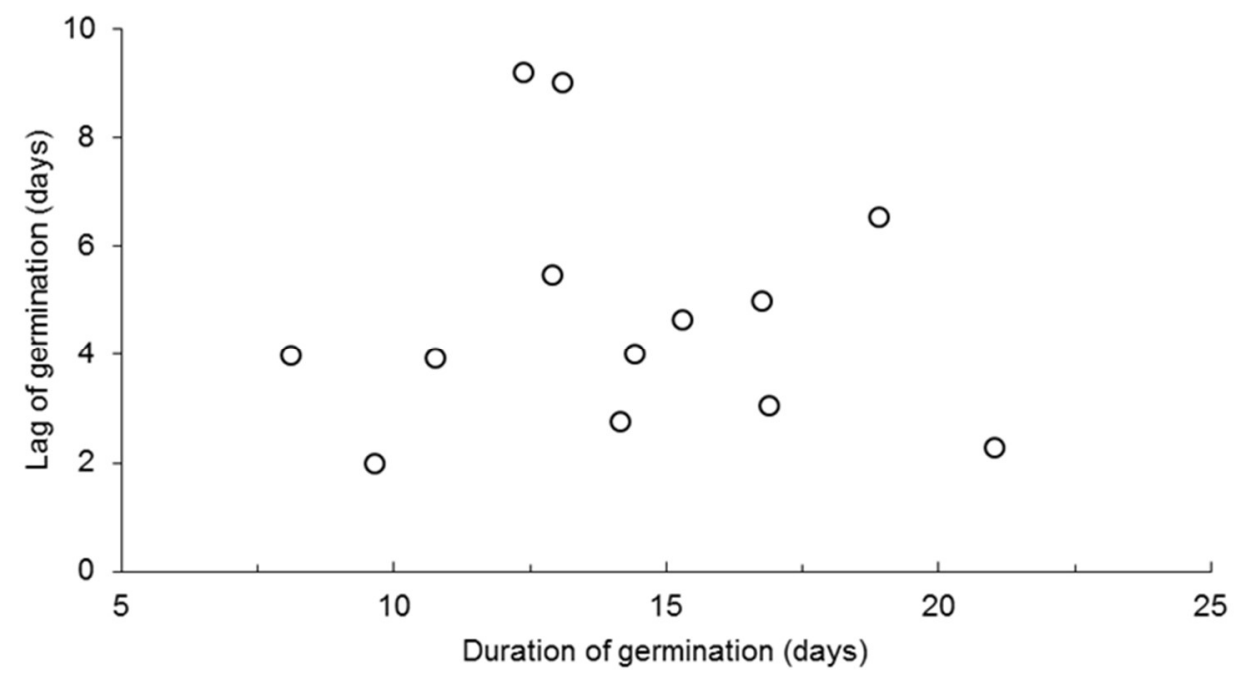

(c)

Figure 2. Biplots of: (a) final germination and time needed for the start of germination (lag); (b) final germination and time needed to the completion of germination minus the lag of germination (duration); (c) lag and duration of germination. 
2.3. Experiment 3: Effects of Heat Shock on Seed Coat Morphology of Cistus ladanifer

Micrographs of representative sites of untreated seeds, of seeds treated with heat or with hexane are presented in Figure 3.
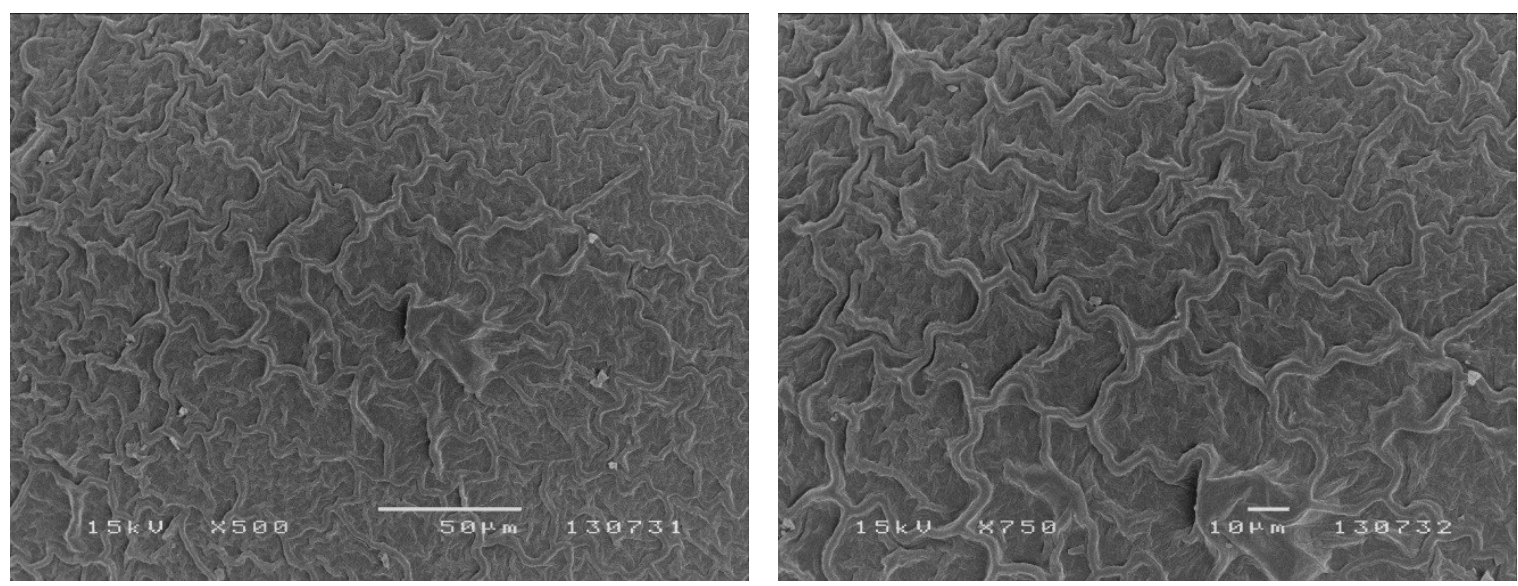

(a)
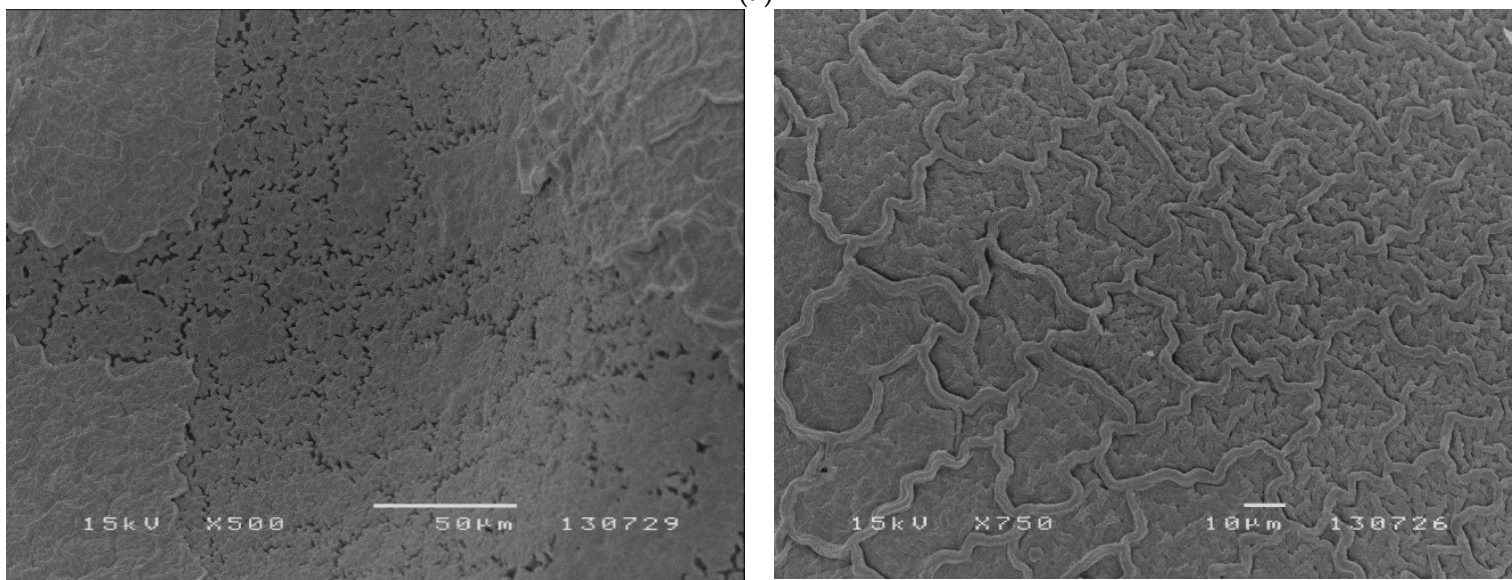

(b)
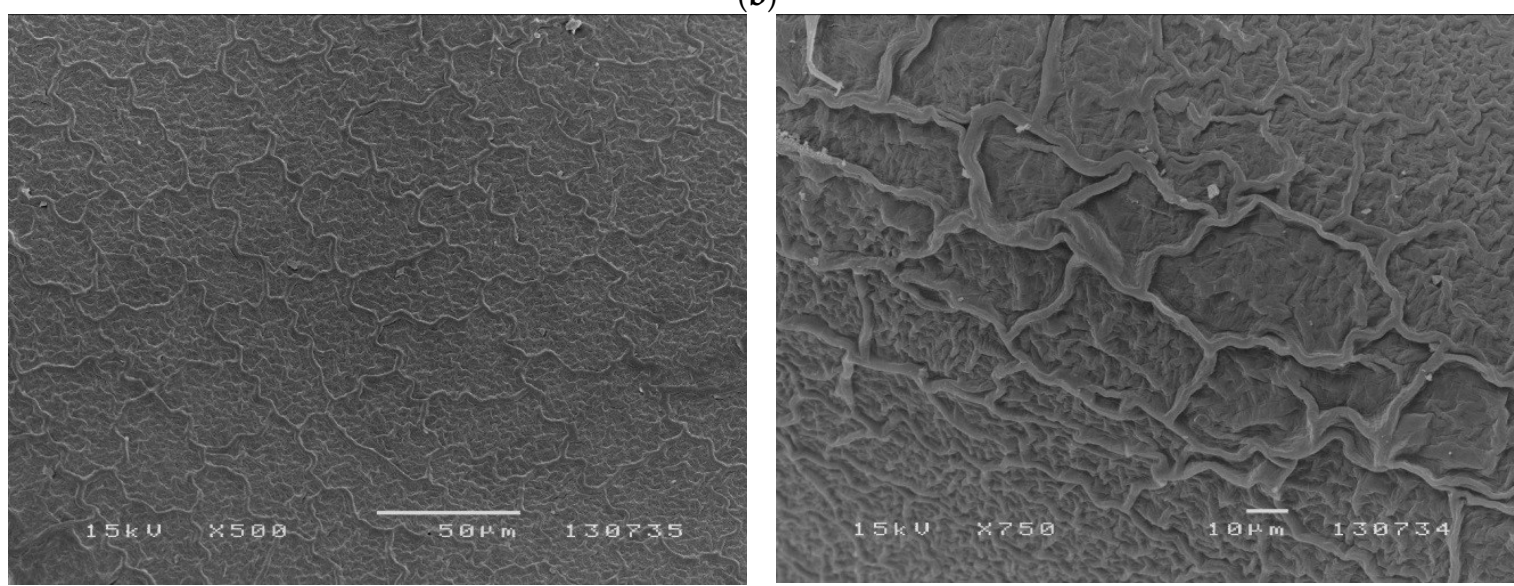

(c)

Figure 3. Seed coat morphology of Cistus ladanifer. Scanning electron photomicrographs at two magnifications of (a) untreated seeds; (b) seeds with epicuticular waxes removed with hexane; (c) seeds treated with $90{ }^{\circ} \mathrm{C}$.

Scanning electron micrographs of untreated seeds of $C$. ladanifer externally show a continuous layer with a reticulate pattern made of irregular ridges (Figure 3a) identical to previous reports of seeds of this species $[15,31]$. Extraction of epicuticular waxes by hexane revealed that the surface of the 
internal layer is flatter with a reticulate pattern of irregular openings coincident with the ridge pattern of the outermost layer (Figure $3 \mathrm{~b})$. Seeds treated with heat $\left(90^{\circ} \mathrm{C}\right)$ resemble very closely untreated seeds except that the reticulate was smoothed and ridges were less prominent (Figure 3c).

\subsection{Experiment 4: Weight Increase of Nongerminated Imbibing Seeds of Cistus ladanifer}

Final germination was $32.3 \pm 2.7 \%$ and was not significantly different from the mean of final germination recorded in the same experimental conditions in Experiment $1\left(t_{10}=1.23, P=0.248\right)$ and in Experiment $2\left(t_{6}=0.11, P=0.210\right), 27.3 \pm 2.5 \%$ and $32.6 \pm 1.2 \%$ respectively (Tables S1 and S2).

Seed weight before imbibition and incubation ranged from $0.184 \mathrm{mg}$ to $0.347 \mathrm{mg}$ (mean $0.282 \pm 0.003 \mathrm{mg}$ ). With few exceptions the weight of all seeds that did not germinate and therefore could be weighed again, increased during the experiment (Table S3), increases having been found in $83.3 \pm 4.8 \%$ of nongerminated seeds.

There was a considerable overlap between the initial weights of seeds that later germinated $(0.184 \mathrm{mg}$ to $0.347 \mathrm{mg}$, mean $0.293 \pm 0.007 \mathrm{mg})$ and those that did not $(0.220 \mathrm{mg}$ to $0.341 \mathrm{mg}$, mean $0.277 \pm 0.004 \mathrm{mg})$, and no significant differences were found between them $\left(t_{84}=2.20, P=0.050\right)$. Therefore germination seems to be independent of the size of seeds contrary to what is frequently the case in other species [29] and cannot be used as a predictor of final germination of C. ladanifer seeds.

Weight increases of nongerminated seeds weighed by initial seed weight before imbibition were relatively low ranging from $0.3 \%$ to $13.0 \%$, with a mean of $4.7 \pm 0.4 \%$.

\subsection{Experiment 5: Dye Uptake by Imbibing Seeds of Cistus ladanifer}

Methyl violet was found inside almost all seeds $(92.9 \pm 4.1 \%)$. In the majority of seeds the whole internal space was dyed but not embryos (Figure 4c). Simultaneously no seed size increases were detectable in $61.6 \pm 1.9 \%$ of seeds. However size visibly increased in a number of seeds in which embryos were dyed (Figure $4 \mathrm{~d}$ ).

Swollen and dyed seed embryos included, amounted to $36.3 \pm 2.7 \%$ of seeds a value that was not significantly different from mean final germination of seeds treated with $30^{\circ} \mathrm{C}$ in Experiment 2 $\left(t_{6}=1.21, P=0.252\right)$ and Experiment $4\left(t_{6}=1.06, P=0.330\right)$ and virtually not significantly different from final germination of seeds treated with $30{ }^{\circ} \mathrm{C}$ in Experiment $1\left(t_{10}=2.32, P=0.050\right), 32.6 \pm 1.2 \%$, $32.3 \pm 2.7 \%$, and $27.3 \pm 2.5 \%$ respectively (Tables S1-S3).

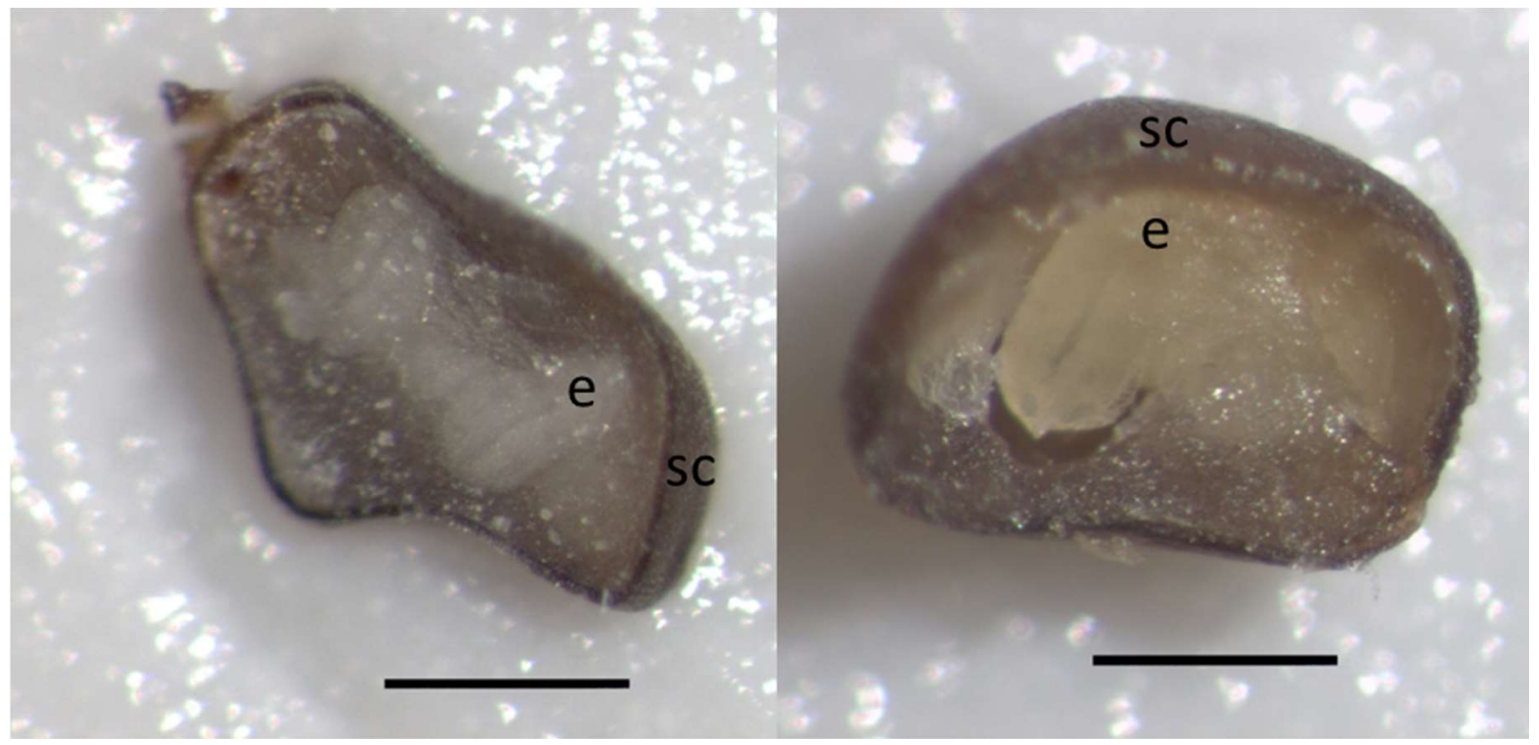

(a)

(b)

Figure 4. Cont. 


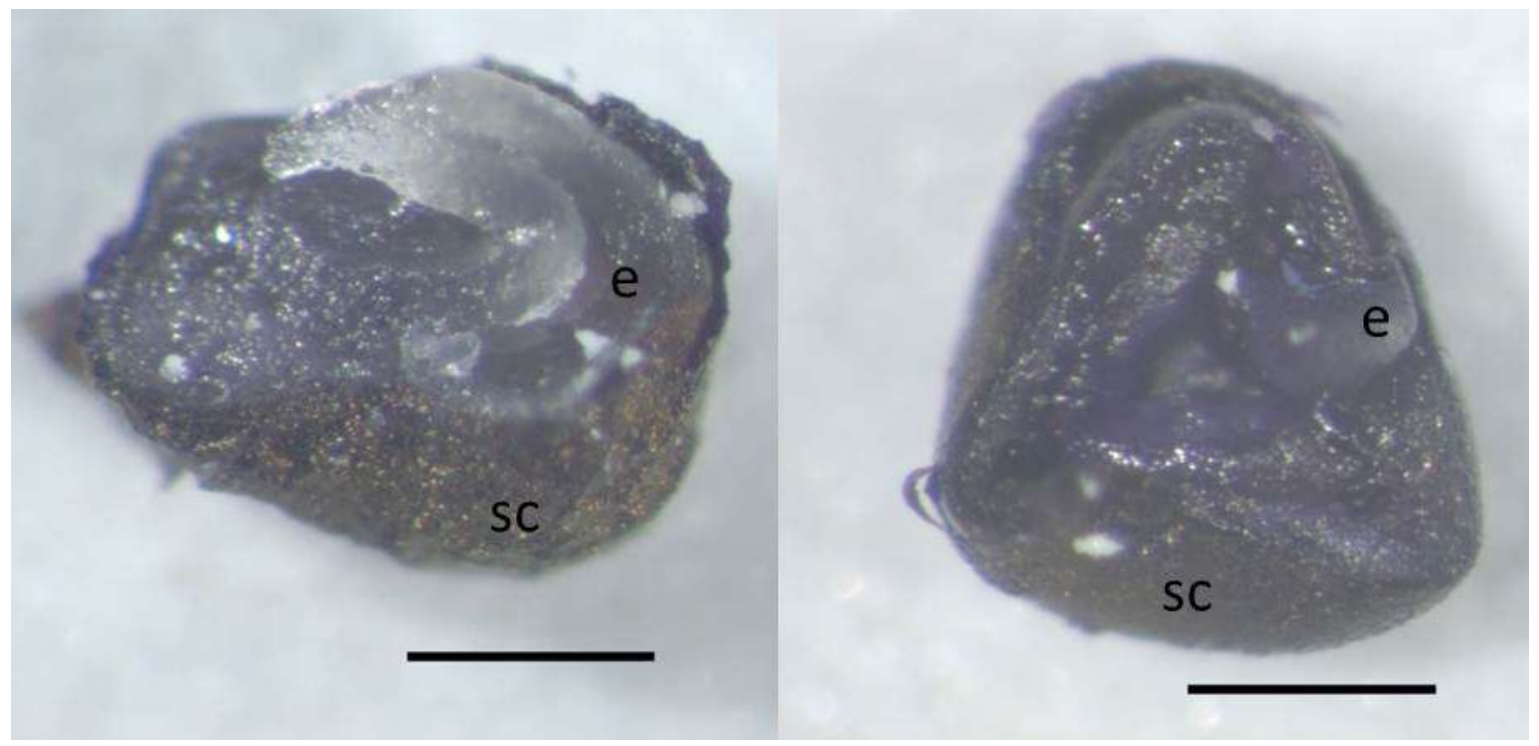

(c)

(d)

Figure 4. Imbibition and uptake of water and dye by seeds of Cistus ladanifer: photomicrographs (a) of dry, nonimbibed seed; (b) swollen seed imbibing with water alone for $48 \mathrm{~h}$; (c) nonswollen seed imbibed with water solution of methyl violet for $72 \mathrm{~h}$; (d) swollen seed imbibed with water solution of methyl violet for 48 h. $e$, embryo; sc, seed coat. Scale bar $=500 \mu \mathrm{m}$.

\subsection{Experiment 6: Effects of Heat Shock on Volume Increase of Imbibing Seeds of Cistus ladanifer}

Almost all swollen seeds visibly took water in the first $72 \mathrm{~h}$ of incubation. In the 6th day of imbibition significant differences $\left(t_{6}=24.29, P \approx 0\right)$ were found between the cumulative percentage of swollen seeds in $30{ }^{\circ} \mathrm{C}$ and $90{ }^{\circ} \mathrm{C}$ treatments, which was $31.0 \pm 2.5 \%$ and $98.0 \pm 1.1 \%$ respectively. Conversely, no significant differences in the percentage of swollen seeds treated with $30^{\circ} \mathrm{C}$ were found between this experiment and Experiment $5\left(t_{6}=1.64, P=0.152\right)$.

Final germination in the same heat treatments of $30^{\circ} \mathrm{C}$ and $90{ }^{\circ} \mathrm{C}$ in Experiment 2 was $32.6 \pm 1.2 \%$ and $100 \pm 0 \%$ (Table S2). No significant differences were found neither in $30{ }^{\circ} \mathrm{C}$ heat treatment $\left(t_{6}=0.58, P=0.583\right)$ nor in $90{ }^{\circ} \mathrm{C}$ heat treatment $\left(t_{6}=1.73, P=0.182\right)$ between the percentages of swollen seeds in this experiment and the final germination in Experiment 2.

\subsection{Depth of Emergence of Cistus ladanifer Seedlings and Soil Temperatures}

\subsubsection{Depth of Emergence of Cistus ladanifer Seedlings}

Maximum hypocotyl length in C. ladanifer seedlings growing in filter paper was reported to be $22.3 \mathrm{~mm}$ [26]. However, from Equation (1) and from data abstracted from literature, maximum depth for successful germination of C. ladanifer in soil would be lesser, only $18.9 \mathrm{~mm}$ [26]. Using Equation (1) and data from individual seed weight of Experiment 4, maximum depth for successful germination of C. ladanifer in soil would range from $11.2 \mathrm{~mm}$ to $19.2 \mathrm{~mm}$ (mean $17.7 \pm 0.1 \mathrm{~mm}$, median $17.8 \mathrm{~mm}$ ). Heavier seeds have been reported thus increasing the depth from which successful germination might occur to $39.6 \mathrm{~mm}$ [15] or to a suspiciously deep $56.0 \mathrm{~mm}$ [32], unless mass data provided by the latter authors refer to a sample of 25 seeds and not to a single seed in which case maximum depth would reduce to a more reasonable $19.1 \mathrm{~mm}$.

\subsubsection{Soil Temperatures during Fires}

Peaks of temperature of $250^{\circ} \mathrm{C}$ can be found during about four minutes at soil surface in a typical chaparral during low burn and around $80{ }^{\circ} \mathrm{C}$ during seven minutes at $2.5 \mathrm{~cm}$ depth. Higher peaks 
were found in moderate and intense burn reaching $430{ }^{\circ} \mathrm{C}$ and $680{ }^{\circ} \mathrm{C}$ during about two minutes at soil surface, $170^{\circ} \mathrm{C}$ and $190^{\circ} \mathrm{C}$ during three and five minutes at $2.5 \mathrm{~cm}$ depth respectively [33].

During fire in late spring in a Quercus coccifera garrigue free from fire in the previous 20 years, temperatures higher than $200{ }^{\circ} \mathrm{C}$ with a maximum of $250{ }^{\circ} \mathrm{C}$ lasted more than two minutes at soil surface while in early autumn temperatures quickly reached $400{ }^{\circ} \mathrm{C}$ and stayed above $200^{\circ} \mathrm{C}$ for more than three minutes. At $2.5 \mathrm{~cm}$ depth a maximum of $125^{\circ} \mathrm{C}$ was registered in late spring half minute after the passage of fire, then dropped to $100{ }^{\circ} \mathrm{C}$ after another half minute, stayed unchanged during the following $5 \mathrm{~min}$, then descended quickly to $80^{\circ} \mathrm{C}$ followed by a slower descent to around $60^{\circ} \mathrm{C}$, while in early autumn temperature exceeded $100{ }^{\circ} \mathrm{C}$ for almost five minutes with a peak at $150{ }^{\circ} \mathrm{C}$, then steadily declined [34].

Temperatures at soil surface during fires may reach $200^{\circ} \mathrm{C}$, while temperatures in the soil profile strongly depend on fire intensity. In light fires temperatures are less than $55^{\circ} \mathrm{C}$ at $3 \mathrm{~cm}$ depth but the same temperatures can be found at $10 \mathrm{~cm}$ depth during very intense fires [35].

Time-course curves for soil temperatures after fires are also available for 50-years-old Adenostoma stands burned in the end of November. At soil surface temperatures in excess of $200{ }^{\circ} \mathrm{C}$ (maximum exceeding $800^{\circ} \mathrm{C}$ ) last approximately nine minutes. At $2 \mathrm{~cm}$ depth the maximum temperature was $140{ }^{\circ} \mathrm{C}$, temperatures above $100^{\circ} \mathrm{C}$ lasting approximately two hours [36].

Similar data was provided for fire temperatures in 12-years old Ulex parviflorus gorse shrublands. At soil surface temperatures exceeding $200{ }^{\circ} \mathrm{C}$ were observed, with a maximum of $409{ }^{\circ} \mathrm{C}$, during approximately $15 \mathrm{~min}$. At $1 \mathrm{~cm}$ depth maximum temperatures ranged from $55^{\circ} \mathrm{C}$ to $229^{\circ} \mathrm{C}$, temperatures above $200{ }^{\circ} \mathrm{C}$ likely to last approximately five minutes then dropping to less than $60^{\circ} \mathrm{C}$ after $20 \mathrm{~min}$ [37]. Graphical interpolation shows that mean maximum temperature at $2 \mathrm{~cm}$ depth would be around $70{ }^{\circ} \mathrm{C}$. These data were collected in autumn after the first rainfalls and higher temperature values would probably be found if soil was dry as usually happens when non-experimental fires are involved.

Nevertheless, ten years after in the same gorse shrublands, maximum temperature at $1-\mathrm{cm}$ depth during an experimental fire ignited in June never exceeded $100{ }^{\circ} \mathrm{C}$ with temperatures higher than $60^{\circ} \mathrm{C}$ lasting two minutes or less while in Cistus albidus stands lower temperatures were found at $1 \mathrm{~cm}$ depth despite that the latter species generally has a greater fuel load than $U$. parviflorus [38].

Profiles of soil temperatures during fires were simulated using a first-order fire effects model [39] and three types of fuel load models selected according to [40]. Fuel load models were FLM015, FLM054 and FLM066, corresponding to shrubs, nonsagebrush with low, medium and high total loads respectively. Pacific West, summer, very dry moisture conditions and loamy-skeletal soil were selected and default values for natural fuel type were always used except that duff load and duff depth were set to zero. Lethal and near-lethal temperatures would be found at soil surface for about three minutes under FLM015 simulation which has litter and shrub loads very similar to those found in mature stands of $C$. ladanifer. At or below 1-cm depth soil temperatures would never be high enough to stimulate C. ladanifer seed germination. Increasing litter and shrub loads, FLM054 and FLM066, lethal temperatures would be found deeper and during more time, noneffective temperatures also deeper, and stimulatory temperatures in a small interval around 2-cm depth.

\section{Discussion}

\subsection{Responses of Seed Germination to Temperature and Light Regime}

Final germination of $C$. ladanifer seeds was unaffected by light and by constant and alternate temperatures of incubation in the range $10^{\circ} \mathrm{C}$ to $30^{\circ} \mathrm{C}$. Similar results have been reported for $\mathrm{C}$. ladanifer and other Cistus $[3,22]$. However, it was also reported that incubation at $15^{\circ} \mathrm{C}$ under dark might favor final germination of $C$. ladanifer seeds [22]. 


\subsection{Responses of Seed Germination to Heat Shock}

The results of final germination of $C$. ladanifer seeds in response to heat shock reported here show only minor and negligible differences from similar bioassays reported in literature $[22,23]$ and fundamentally leaves the overall picture provided by them unchanged. However the wider range of temperatures tested and the dose-response approach adopted provide a more detailed understanding of such responses.

Final germination increased with temperature until $90^{\circ} \mathrm{C}$ to decrease thereafter. However no significant differences were found in final germination of seeds treated with $70{ }^{\circ} \mathrm{C}$ or less, where a non-negligible fraction of around $40 \%$ of seeds germinated.

Nevertheless heat shock alone increased final germination of $C$. ladanifer with a sharp increase to almost $90 \%$ at $80^{\circ} \mathrm{C}$. From equations fitted to data of Experiment 2 final germination would exceed $95 \%$ for heat treatments between $83^{\circ} \mathrm{C}$ and $97^{\circ} \mathrm{C}$. The maximum was observed at $90^{\circ} \mathrm{C}$, a treatment where all seeds germinated. The viability of $C$. ladanifer seeds used in this experiment was not investigated per se but the high germination rates observed in seeds treated with temperatures between $80^{\circ} \mathrm{C}$ and $100{ }^{\circ} \mathrm{C}$ makes a strong argument against considering lack of viability as an explanation for failure of germination in the other heat treatments.

At $140{ }^{\circ} \mathrm{C}$ or above all seeds were rotten and heavily preyed by microbes which might result from thermal destruction or inactivation of phytoncides known to be present in seeds of $C$. ladanifer [31,41].

Heat shock also affected other aspects of germination. The reduction of lag of germination, meaning a significant trend for a faster initiation of germination with increasing temperatures was found in heat treatments below $100{ }^{\circ} \mathrm{C}$. Seeds treated with $90{ }^{\circ} \mathrm{C}$ were the fastest, initiating germination only less than two days after incubation, slightly less than in seeds treated with $80^{\circ} \mathrm{C}$, bordering the status of very fast germinating seeds [42,43]. Overall, two major groups could be identified in relation to the time necessary for germination to start. One group of fast seeds largely coincident with the group of high final germination rates the exception located at heat shock $100^{\circ} \mathrm{C}$, and one group of slow seeds essentially including heat treatments below $80^{\circ} \mathrm{C}$ and above $100^{\circ} \mathrm{C}$.

Time necessary to attain final germination after the lag phase and shape of germination were almost never affected with the pooled mean for the latter excluding the $90{ }^{\circ} \mathrm{C}$ treatment neared the upper limit of symmetric distribution. Therefore factors governing the germination of C. ladanifer appear to act additively or quasi-additively across almost all heat treatments. By the contrary the negative asymmetric distribution in seeds treated with $90^{\circ} \mathrm{C}$ implies that factors governing germination after that treatment act nonadditively [44].

In short, final germination of $C$. ladanifer is enhanced by heat shock in the range $80-100{ }^{\circ} \mathrm{C}$ with maximum germination at $90{ }^{\circ} \mathrm{C}$, which is also the heat shock treatment responsible for the fastest initiation of germination and for one of the two fastest completions of germination.

This range of optimal temperatures for final germination is not exclusive of $C$. ladanifer and is found in a variety of other species from fire-prone ecosystems [26,45-50] strongly suggesting that it represents what may be a generalized adaptive response to recurrent fires. However the discussion of whether it is in fact an adaptation or an exaptation [51-54] is beyond the scope of this paper.

\subsection{Responses of Water Uptake by Seeds to Heat Shock}

The explanation more frequently presented in the literature to account for the promotion of seed germination of $C$. ladanifer by fire involves the rupture of seed coats by heat shock presumably because seed coats in C. ladanifer are impermeable to water and act as a barrier to its uptake [15,22-24]. Experimental research has evidenced that such process is in place in a number of other species [55-59] with conflicting evidences in others [60,61]. Nevertheless a screen of literature fails to show experimental support to that assumption in C. ladanifer. Only anecdotal and inconclusive evidence exist, derived from the structure and composition of seed coats [15,31] or from experiments where seeds were scarified with sulphuric acid $[23,28]$, razor blades or sand paper $[3,26,62,63]$. Scarification 
was found to have smaller effects on C. ladanifer germination than heat shock $[23,26]$ while in other Cistus smaller [28], equal [62] or larger [3] effects have been found.

Contrary to what should be expected from the hypothesis of seed coat rupture, no cracks or fractures were found in SEM observations as a result of heat shock by $90{ }^{\circ} \mathrm{C}$ during $15 \mathrm{~min}$. Even the reticulate pattern of openings below the waxy external layer of seed coats, and seemingly coincident with ridges of the latter, are not made visible by heat shock.

However, the small number of seeds examined and the practical impossibility of examining the entire seed coat prevent definitive conclusions on whether or not heat shock result in mechanical rupture of seed coats, which is presumed to be one pre-requisite for water uptake of seeds of C. ladanifer.

It should be emphasized that the putative impermeability of seed coats in C. ladanifer can only affect a fraction of the seeds. In fact, as repeatedly shown in this and other studies, provided that water is available, at least around one third of seeds of this species complete germination in a relatively short period without any treatment. In addition, percentages of germination as high as $60 \%$ were reached when seeds of $C$. ladanifer were treated with water solutions of a variety of nitrogenous compounds, and as high as $80 \%$ when treated with water suspensions of charred wood [64] despite that seeds were never subjected to temperatures above $24{ }^{\circ} \mathrm{C}$. The almost inevitable conclusion is that at least $80 \%$ of those seeds, a large part of which are usually presumed to have physical dormancy, took water despite that no rupture of their seed coats happened. As far as we know this is a point that has never been addressed before but indicates that dormancy in $C$. ladanifer seeds can hardly be related with seed coats.

Most part of nongerminated seeds (83\%) increased weight after five weeks of imbibition in the absence of heat shock, but a total of 11 seeds lost weight after imbibition (Table S3), a result that has been occasionally reported for other species, namely Amaranthus hybridis [65] and might result from the loss of seed materials to water [66]. Such losses might be more common than reported in literature if individual seeds as reported here, instead of batches, as usually done, were weighed. Our data support this statement in the case of $C$. ladanifer. The more frequent weight increases vastly superseded weight losses. Total weight loss of nongerminated seeds amounted to $0.065 \mathrm{mg}$ which was vastly exceeded by the total weight gain of $0.682 \mathrm{mg}$.

However weight increases by imbibition noticeably larger than the relatively small increases we found with $C$. ladanifer were reported in other species without effective passage of water through seed coat [67]. However the use of methyl violet showed that with few exceptions water uptake in C. ladanifer is not prevented by seed coats because the dye was found inside $93 \%$ seeds. Additionaly seed imbibition was relatively fast because the whole experiment was completed in 72 hours.

Despite being found inside almost all seeds, with few exceptions methyl violet was only found inside embryos of seeds visibly swollen. In addition the percentage of swollen seeds with dyed embryos essentially coincided with the percentage of non-dormant seeds found throughout this study. Assuming that the movement of methyl violet is a reliable indicator of water movement, the absence of dye in embryos of non-swollen seeds suggests that some type of barrier to the movement of water exists in dormant seeds of $C$. ladanifer somewhere between the endosperm and the embryo, thus preventing germination. Such a barrier would be eliminated by heat shock thus increasing the imbibition of embryos.

Finally the swelling of seeds was assumed as an indicator that water had been taken by embryos, and an almost perfect agreement was found between percentages of swelling in seeds treated with $30^{\circ} \mathrm{C}$ or with $90^{\circ} \mathrm{C}$ and percentages of final germination of seeds treated in the same manner.

Nevertheless, and whatever the pathways for water entry our results lead to the conclusion that almost all seeds imbibe in the absence of any treatment. Thus the seed coat is not a barrier to water uptake by $C$. ladanifer seeds and the widely recorded stimulation of germination by heat shock is not the result of increased permeability to water brought by mechanical rupture of seed coat. Further research is necessary to elucidate the exact processes responsible for dormancy breaking in seeds of C. ladanifer. 


\subsection{Ecological Significance of Seeds Response to Heat Shock}

The evaluation of the ecological significance of the response of seed germination of $C$. ladanifer to heat shock requires some knowledge on whether temperatures tested in heat shock experiments including lethal ones are found in soils during fires, and on maximum depths allowing successful emergence of $C$. ladanifer plantlets.

Nevertheless, an important fraction of C. ladanifer seeds have the ability to germinate in the absence of heat shock at temperatures likely to be found in soil during winter months. Seeds of C. ladanifer are held in capsules, broadly 500-1000 seeds per capsule [24], which can easily result in hundreds of thousands of seeds being added every year to the soil seed bank by a single plant, especially in plants growing in dense stands, very close to conspecifics [68] setting the basis for a large recruitment of new seedlings. Field data supports this conclusion even if at lower rates than could be expected from laboratory results. In fact, the number of $C$. ladanifer seedlings in cut plots can be as much as $20 \%$ of the number of seedlings in burnt plots [69]. However, when vegetation is present the contribution of this fraction to the appearance of new individuals is likely to be negligible in the field because seedling recruitment in C. ladanifer and other Cistus was found to be almost absent in unburned areas under mature canopies [12,13] probably because seedling survival is prevented by canopy shading or because seed germination was previously auto-inhibited by allelopathins [70].

The maximum depth for successful emergence of Mediterranean grassland species as been set at $10 \mathrm{~mm}$ [71] and seeds of Mediterranean species are frequently positively photoblastic requiring light to germinate [72]. However such requirement is apparently absent in C. ladanifer seeds, which might allow them to germinate from depths below $10 \mathrm{~mm}$. The maximum elongation of $C$. ladanifer hypocotyls growing in filter paper under dark was found to be $22.3 \mathrm{~mm}$ [26], which might be an overestimation given the reduced resistance to elongation in these experimental conditions. Therefore, and according to our data and to literature, $20 \mathrm{~mm}$ can be assumed to be the maximum depth from which seeds of $C$. ladanifer can successfully germinate and reach soil surface. Some reports make higher depths conceivable but if proven true they would be so deep that the insulation provided by soil would prevent fire-driven increases in seed germination. Nevertheless fires may remove soil from the surface bringing deeper seeds to shallower depths, an indirect but frequent post-fire effect in the Mediterranean basin, its intensity increasing with fire intensity [73]. Thus recruitment of a large number of new plants would still be possible because about one third or more of seeds are able to germinate without heat shock.

Fire effects on soil are known to be extremely variable and heterogeneous either at soil surface or at deeper levels [36] and it has been suggested that lethal temperatures occur in soils during fires but generally confined to the soil surface $[45,74]$. To our knowledge no data exist on time-temperature distributions in soil during fires in C. ladanifer stands. However, data from communities with comparable characteristics provide useful cues to evaluate whether temperatures tested in heat shock experiments occur in the soil during fires.

A search in literature reveals a considerable variability in soil temperatures and depth distribution during fires, even if only communities similar to C. ladanifer stands are considered. Nevertheless a general picture emerges, in which at soil surface all or near all seeds would be killed by temperatures resulting from the passage of fire. Depending on the speed of burn and on the fuel load present lethal heat loads can occur at increasing depths $[23,33]$ suggesting that at least at small scales, all seeds located at soil depths shallow enough to allow the renewal of $C$. ladanifer stands would be destroyed by fire and no renewal of $C$. ladanifer stands would occur unless the removal of superficial soil layers referred above would operate and allow the successful germination of seeds.

Finally it is conceivable that heat loads resulting from the passage of fire might be too low to enhance the germination of seeds of $C$. ladanifer but nevertheless burn all or nearly all herbs and shrubs aboveground. In such event, the regeneration of $C$. ladanifer stands would rest in the non-dormant fraction of its seedbank which, as noted above, is large enough to make it possible, a capacity that might lend some arguments to the debate on the adaptation or the exaptation nature of the responses of $C$. ladanifer seeds to heat shocks brought by fire. 
In short, a sizable fraction of $C$. ladanifer seedbanks is likely to be destroyed by fire and only seeds buried in a very narrow range of depth would be stimulated by the appropriate heat loads during fires. Nevertheless, as remarked above fire is a phenomenon extremely variable and heterogeneous either at soil surface level or through the soil profile and in its passage a variety of heat loads are produced and seeds of $C$. ladanifer would respond in a variety of ways depending on their dormancy characteristics. Therefore, the 'window' of germinability [75] might be highly expanded and respond to fire characteristics and soil temperatures in a very flexible mode.

After being destroyed by fire, regeneration of $C$. ladanifer stands completely depends upon soil seedbanks. C. ladanifer is known to germinate very quickly after the first rains post-fire with germination occurring predominantly during the first year. As discussed above such recruitment can result from the germination of seeds whose dormancy has been removed by fire, fire being a sufficient but not necessary condition because in all likelihood the fraction of non-dormant seeds would be enough to post-fire recovery of $C$. ladanifer stands. Mortality is lower for first-year seedlings and is closely related to weather conditions like frost and dry periods occurring soon after germination took place. Nevertheless even the seedling cohorts with higher survival may have as much as $50 \%$ mortality after less than six months [2]. Anyway, in 3-4 years plants reach maturity, seed production resumes [68] and seedbanks replenish.

\section{Materials and Methods}

\subsection{Seed Collection}

Seeds were collected in early summer near Valverde (approximately $38^{\circ} 31^{\prime} 58^{\prime \prime} \mathrm{N}, 8^{\circ} 01^{\prime} 33^{\prime \prime} \mathrm{W}$ ), Évora, Southern Portugal. During the 30-year period 1971-2000, yearly rainfall in the area slightly exceeded $600 \mathrm{~mm}$ with a very dry period (months with less than $1.5 \%$ of yearly rainfall) in July and August. Monthly mean air temperatures (maximum/minimum) were $30.2{ }^{\circ} \mathrm{C} / 16.3{ }^{\circ} \mathrm{C}$ and $12.8^{\circ} \mathrm{C} / 5.8^{\circ} \mathrm{C}$ in the hottest (July or August) and coolest (January) month respectively. The climate of Évora region is Mediterranean, mild with dry hot summers, Csa using the Köppen classification system [76].

Ripe capsules of $C$. ladanifer (subsp. ladanifer) that showed no evidence of predation were harvested from two, maximum three neighboring plants about $1.5 \mathrm{~m}$ tall located in the edge of a relatively dense stand of Eucalyptus globulus facing East. Seeds were extracted from capsules, stored in paper envelopes, and kept under dark at room temperature.

\subsection{Experiments 1 and 2: Germination Experiments}

Four replicates of 25 seeds of $C$. ladanifer were used for each treatment in all germination experiments. Seeds were sown in $10-\mathrm{cm} \varnothing$ glass Petri dishes with Whatman No. 1 filter paper, wetted with $3.5 \mathrm{~mL}$ of distilled water and as needed thereafter, incubated in light- and temperature-controlled incubators, checked 2-3 times a week and removed when germinated. Germination was scored when the embryo, normally the radicle, protruded from the seed coat and exceeded the largest dimension of the seed [77]. Experiments were continued until no new germination had been recorded for seven consecutive days.

\subsubsection{Experiment 1: Effects of Temperature and Light Regime on Final Seed Germination}

This experiment was aimed to assess the responses of final germination of seeds of $C$. ladanifer to different temperatures, to constant and alternate temperatures, and to the presence or absence of photoperiod. Seeds were assayed at different temperatures regimes and light conditions to test whether germination varied across a range of incubation temperatures and light regimes. Incubators were set at constant temperatures ranging from $10{ }^{\circ} \mathrm{C}$ to $30^{\circ} \mathrm{C}$ (at $5{ }^{\circ} \mathrm{C}$ intervals) and at alternating temperatures under $16 / 8 \mathrm{~h}$ cycles at $10 / 20^{\circ} \mathrm{C}, 15 / 25^{\circ} \mathrm{C}$ and $20 / 30^{\circ} \mathrm{C}$, and a photoperiod of $8 \mathrm{~h}$ simultaneous with the higher temperature in the alternating temperatures. Two additional sets of four Petri dishes each 
were later prepared, one wrapped in aluminum foil and black plastic, and incubated in dark under constant $20^{\circ} \mathrm{C}$ (dark treatment) the other incubated under constant $20^{\circ} \mathrm{C}$ and a photoperiod of $8 \mathrm{~h}$ (light treatment). Germination was monitored during 5 weeks and checked during the light period. In the dark treatment seeds were examined in a dark chamber under dim green-filtered light.

\subsubsection{Experiment 2: Effects of Heat Shock on Seed Germination}

This experiment aimed to assess the effects of heat shock on germination of $C$. ladanifer seeds, described by final germination and by lag, rate and shape of germination, thereby considering the whole process and separately examining its end, represented by final germination, and the path taken to attain it [78]. Seeds were treated under dry conditions during 15 min with constant temperatures ranging from $10^{\circ} \mathrm{C}$ to $150^{\circ} \mathrm{C}$ (at $10^{\circ} \mathrm{C}$ intervals) in refrigerated cabinet or electric oven. Heat treatments were applied for $15 \mathrm{~min}$ because it is unlikely that seeds of $C$. ladanifer might successfully emerge in soils below $25 \mathrm{~mm}$ [26], a depth at which heat waves were found to last $15 \mathrm{~min}$ [34] in ecosystems closely resembling those dominated by $\mathrm{C}$. ladanifer. Typically, for the $90{ }^{\circ} \mathrm{C}$ treatment, opening the oven to introduce the seeds caused temperature to drop less than $2^{\circ} \mathrm{C}$, with the intended temperature being restored after 2-3 min. After heat treatments, seeds were left in closed and dry environment for no more than one hour, transferred to Petri dishes, wetted and incubated under constant $20^{\circ} \mathrm{C}$ with a photoperiod of $8 \mathrm{~h}$. Logistic constraints prevented us to perform all bioassays simultaneously and when the second series of bioassays was done some randomly selected treatments were repeated to control the consistency of responses. The $120{ }^{\circ} \mathrm{C}$ and $130{ }^{\circ} \mathrm{C}$ were also repeated because when first performed no germination was found in too many dishes to allow for fitting Equation (3) to at least two samples and again some randomly selected treatments were repeated to control the consistency of responses. Therefore two sets of four replicates each were separately tested in treatments $20^{\circ} \mathrm{C}, 40{ }^{\circ} \mathrm{C}$, $60^{\circ} \mathrm{C}, 70^{\circ} \mathrm{C}, 110^{\circ} \mathrm{C}, 120^{\circ} \mathrm{C}$, and $130^{\circ} \mathrm{C}$ and germination data pooled together (Table S2). Germination was monitored for 6 weeks during the light period.

\subsection{Experiment 3: Effects of Heat Shock on Seed Coat Morphology}

This experiment aimed to investigate the surface of seed coats of $C$. ladanifer and to assess visually the effects of heat shock on the outermost seed coat integument using as term of comparison the removal of the waxy external layer of seed coats by an organic solvent. Three batches of 10 seeds each were used. Seeds of batch 1 received no treatment. Seeds of batch 2 were stirred 10 min with $5 \mathrm{~mL}$ hexane to remove the epicuticular waxes known to constitute the external layer of $C$. ladanifer seed coats [31,41]. After three extractions, seeds were washed with distilled water and dried with blotting paper. Seeds of batch 3 were treated during $15 \mathrm{~min}$ with $90{ }^{\circ} \mathrm{C}$ in an electric oven (dry heat) and cooled in dry air. Seeds from the three batches were separately mounted on holders with double-sided adhesive carbon ribbon, sputter-coated with gold (JEOL-JFC/1200), observed and photographed using a scanning electron microscope (JEOL, J.S.M. $5200 \mathrm{LV}$ ) at $15 \mathrm{kV}$.

\subsection{Experiments 4-6: Water Uptake by Seeds}

\subsubsection{Experiment 4: Weight Increase of Nongerminated Imbibing Seeds}

This experiment aimed to investigate whether nongerminated seeds that had not been treated with heat had imbibed. One-hundred seeds were treated with $30^{\circ} \mathrm{C}$ as described in Experiment 2, individually weighed to the nearest $\mu$ g, transferred to four Petri dishes fitted with filter paper, 25 seeds per dish, individually identified, wetted with $5 \mathrm{~mL}$ of distilled water and incubated under constant $20^{\circ} \mathrm{C}$ with a photoperiod of $8 \mathrm{~h}$. Germination was monitored during five weeks during the light period and germinated seeds removed. Afterwards nongerminated seeds were dried with blotting paper, checked under a hands lens and again individually weighed to the nearest $\mu$ g. During the second weighing one seed was lost; three were found to be empty from the beginning, 11 lost weight after imbibition (Table S3). Altogether these 15 seeds were not considered in weight analyses. 


\subsubsection{Experiment 5: Dye Uptake by Imbibing Seeds}

This experiment aimed to investigate which structures of seeds not subjected to heat shock took water during seed imbibition, evaluated by the presence of methyl violet. Four Petri dishes with 25 seeds each were treated with $30{ }^{\circ} \mathrm{C}$ as described in Experiment 2 and wetted with $5 \mathrm{~mL}$ of $0.5 \%$ water solution of methyl violet. An additional Petri dish was wetted with $5 \mathrm{~mL}$ of distilled water and used as control. After $72 \mathrm{~h}$ excess solution was removed with blotting paper, seeds carefully cleansed with distilled water, dried with blotting paper, sectioned with a scalpel, and the presence of the dye inside seeds visually checked under a stereomicroscope Leica Zoom 2000. Representatives of swollen or non-swollen seeds dyed or not, and of dry seeds used as control were photographed using a Leica DC 300 mounted on a Wild M8 stereomicroscope.

Methyl violet was the second dye used. Following [55] Congo red was used before and never observed inside seeds, presumably because of its tendency to self-aggregation [79,80]. The same executioners following the same procedures sectioned seeds wetted with Congo red or methyl violet. Therefore the absence of the former inside seeds leads us to discard the suspicion that the presence of methyl violet inside seeds could have been a contamination during seeds sectioning with the scalpel.

\subsubsection{Experiment 6: Effects of Heat Shock on Volume Increase of Imbibing Seeds}

This experiment aimed to compare the effects of $30^{\circ} \mathrm{C}$ and $90^{\circ} \mathrm{C}$ heat treatments on the percentage of $C$. ladanifer seeds that visibly had their volume increased during imbibition before germination started. Seeds were treated with $30{ }^{\circ} \mathrm{C}$ and $90{ }^{\circ} \mathrm{C}$ and subsequently incubated as described in Experiment 2. Four Petri dishes per treatment with 25 seeds each were wetted with $5 \mathrm{~mL}$ of distilled water. Seeds were examined during 6 days at various intervals under a stereomicroscope Leica Zoom 2000 , swollen seeds recorded and discarded. The experiment was continued until no new swollen seed was recorded for two consecutive days.

\subsection{Depth of Emergence and Soil Temperatures}

Depth of maximum emergence of $C$. ladanifer seedlings was determined combining data of hypocotyl growth [26] and maximum depth of seedling emergence estimated using the allometric relationship between depth of successful seedling emergence in soil (SED) and seed mass $\left(W_{\mathrm{s}}\right)$ expressed in $\mathrm{mm}$ and $\mathrm{mg}$ respectively [81]:

$$
S E D=27.3 W_{\mathrm{s}}^{0.334},
$$

Data of published mean values of $C$. ladanifer seed mass $[15,24,26,32,82]$ and of seeds weighed in Experiment 4 were used for that purpose.

Data for soil temperatures during fires were obtained from a variety of sources including published time-course temperature curves [33-38] and from simulations using a first order fire effects model [39].

\subsection{Data Analyses}

Comparisons between two means were done by exact or approximate two-tailed Student's $t$ tests with comparison-wise type I error rates of 0.05 after checking for homoscedasticity using the two-tailed $F$ distribution with a comparison-wise type I error rate of 0.05 . Whenever comparisons among several means were intended, homoscedasticity was tested and when heteroscedasticity was found, Box-Cox transformations [83] were used. In multiple comparisons of means lack of "transitivity" is frequent [84]. To prevent its occurrence a least squares linear regression approach with dummy variables was adopted, and forward stepwise selection with replication was used with candidate models including only the treatments binary coded as $(1,0)$, with an experiment-wise type I error rate of 0.05 for coefficients calculated using Dunn-Šidak method [85]. Lack of fit was always tested and coefficients of determination $\left(R^{2}\right)$ are presented as proportion of the maximum $R^{2}$ possible [86]. 
Likewise when least-squares linear regression was done with measured explanatory variables alone as in the power law fitted to lag of germination in Experiment 2:

$$
l=a H^{-b},
$$

where $l$ is the lag of germination determined from Equation (3), $H$ is the heat treatment and $a$ and $b$ are constants.

Lag, rate, and shape of germination were separately obtained for each replicate in Experiment 2 from the three-term Weibull function [87] fitted by least squares nonlinear regression without replication using the Marquardt method [88]. The three-term Weibull function can be expressed as:

$$
G_{\mathrm{T}}=1-\exp \left\{-[(T-l) / k]^{c}\right\}
$$

where $G_{\mathrm{T}}$ is the cumulative germination at time $T$ in proportion of final germination registered at the end of the bioassay; l (lag of germination) is a location parameter that estimates the latest time at which germination is strictly zero, which in practice represents the time necessary for the first seed to complete germination; $k$ (rate of germination) is a scale parameter estimating the rate of germination completion over time with $l+k$ estimating the time necessary for the completion of $63 \%$ of cumulative germination; $c$ is a dimensionless shape parameter estimating the symmetry of the distribution of germination over time, with $3.25 \leq c \leq 3.61$ showing symmetry and representing a good approximation to the normal distribution, $c<3.25$ positive asymmetry, $c>3.61$ negative asymmetry [89,90]. Fitted equations were only accepted after a consistency check of parameter estimates and germination predictions against the original data $[78,91]$. Duration of germination $\left(D_{100}\right)$, the number of days necessary to attain final germination minus the number of days necessary for germination to start $(l)$ was deduced from fitted equations.

A number of models, including a variety of polynomials were fitted to original data, to means, or to $Q$-splined means [92] and failed to satisfactorily accommodate the whole range of responses of final germination to heat treatments. Therefore regressing final germination on heat treatments was separately investigated for the means of segments $10-70{ }^{\circ} \mathrm{C}, 70-90{ }^{\circ} \mathrm{C}$, and $90-140{ }^{\circ} \mathrm{C}$ by nonlinear regression using a reparameterized Weibull function (Equation (3)) setting $l=90$. Thus:

$$
G_{\mathrm{F}}=\exp -\left\{[(H-90) / x]^{z}\right\},
$$

where $G_{\mathrm{F}}$ is the percentage of final germination at heat treatment $H, x$ and $z$ are equivalent to $k$ and $c$ in Equation (3).

Data are presented as mean \pm SE. Linear regressions, nonlinear regressions and ANOVAs were performed using Statgraphics Plus v. 3.3 (Manugistics, Rockville, MD, USA); determination of Box-Cox transformations using BIOM (Applied Biostatistics, New York, NY, USA); all other statistical analyses using Microsoft Excel ${ }^{\circledR} 2010$.

Supplementary Materials: The following are available online at: http:/ /www.mdpi.com/2223-7747/8/3/63/s1, Table S1: Mean \pm SE of final germination of Cistus ladanifer seeds incubated under constant and alternate temperatures $(16 / 8 \mathrm{~h}$ cycles) and photoperiod $(8 \mathrm{~h})$ simultaneous with the highest temperature; Table S2: Mean \pm SE (sample size $n$ inside parentheses) of final germination, and of lag, rate, duration and shape of germination of Cistus ladanifer seeds incubated under constant temperature $\left(20^{\circ} \mathrm{C}\right)$ and photoperiod $(8 \mathrm{~h})$ after heat treatments $(15 \mathrm{~min}$.); Table S3: Weight of seeds of Cistus ladanifer not treated with heat before imbibition started $\left(\mathrm{W}_{\mathrm{s}}\right)$, of nongerminated seeds after no more germination was recorded $\left(\mathrm{W}_{\mathrm{f}}\right)$ and gain/loss of weight weighed by $\mathrm{W}_{\mathrm{s}}(\Delta)$.

Author Contributions: Conceptualization, L.S.D., I.P.P. and A.S.D.; Formal analysis, L.S.D.; Investigation, L.S.D., I.P.P. and A.S.D.; Methodology, L.S.D., I.P.P. and A.S.D.; Writing—original draft, L.S.D.; Writing—review \& editing, L.S.D. and A.S.D.

Funding: This research received no external funding.

Acknowledgments: We are thankful to Gertrudes Grenho in germination experiments; to Telmo Nunes in SEM micrographs; to Manuela Carrott for the facilities made available to us in Experiment 4; to Orlando Lopes and 
Mónica Lima in SEM and light micrographs, the former also in directing us to methyl violet; to Paulo Fernandes and Carlos Alexandre for all the support and clarifications in the use of FOFEM. G.G., O.L., M.L. affiliated to Department of Biology, University of Évora; T.N. to Department of Plant Biology, University of Lisboa; M.C. to Department of Chemistry, University of Évora; P.F. to Department of Forest Sciences Landscape Architecture, University of Trás-os-Montes e Alto Douro; C.A. to Department of Geosciences, University of Évora. And also to two anonymous reviewers for comments, suggestions, and corrections made to earlier versions of this paper.

Conflicts of Interest: The authors declare no conflict of interest.

\section{Appendix A}

Heteroscedasticity among samples was always found in Experiment 2 and comparison of means was always performed after Box-Cox transformation of data. Lambda values were $\lambda=0.98083$, $\lambda=-0.10522, \lambda=-0.04203, \lambda=-0.72638$, for final germination, lag of germination, $D_{100}$, and shape of germination respectively.

Significant differences among means were found in final germination of seeds $\left(F_{4,75}=21.77, P \approx 0\right.$, $R^{2}=0.872$, lack of fit with $\left.F_{8,67}=1.71, P=0.111\right)$; in lag of germination $\left(F_{4,48}=9.94, P \approx 0, R^{2}=0.705\right.$, lack of fit with $\left.F_{11,40}=2.66, P=0.019\right)$; in $D_{100}\left(F_{1,51}=7.46, P=0.009, R^{2}=0.393\right.$, lack of fit with $\left.F_{11,40}=1.06, P=0.415\right)$; in shape of germination $\left(F_{1,51}=12.0, P=0.001, R^{2}=0.573\right.$, lack of fit with $\left.F_{11,40}=0.774, P=0.663\right)$.

\section{References}

1. Keeley, J.E.; Fotheringham, C.J. Role of fire in regeneration from seed. In Seeds. The Ecology of Regeneration in Plant Communities, 2nd ed.; Fenner, M., Ed.; CABI Publishing: Wallingford, UK, 2000; pp. 311-330, ISBN 0-85199-432-6.

2. Quintana, J.R.; Cruz, A.; Fernández-González, F.; Moreno, J.M. Time of germination and establishment success after fire of three obligate seeders in a Mediterranean shrubland of central Spain. J. Biogeogr. 2004, 31, 241-249. [CrossRef]

3. Thanos, C.A.; Georghiou, K. Ecophysiology of fire-stimulated seed germination in Cistus incanus ssp. creticus (L.) Heywood and C. salvifolius L. Plant Cell Environ. 1988, 11, 841-849. [CrossRef]

4. Thanos, C.A.; Georghiou, K.; Kadis, C.; Pantazi, C. Cistaceae: A plant family with hard seeds. Isr. J. Bot. 1992, 41, 251-263. [CrossRef]

5. Sanders, T.W. Sander's Encyclopaedia of Gardening, 22nd ed.; W.H. and L. Collingridge: London, UK, 1956.

6. Brickell, C. The Royal Horticultural Society Gardeners' Encyclopedia of Plants E Flowers; Dorling Kindersley: London, UK, 1994; ISBN 0-7513-014-77.

7. Braun-Blanquet, J.; Silva, A.R.P.; Rozeira, A. Résultat de trois excursions géobotaniques à travers le Portugal septentrionel et moyen. III Landes à Cistes et Ericacées (Cisto-Lavanduletea et Calluno-Ulicetea). Agron. Lusit. 1961, 23, 229-312.

8. Goday, S.R. Vegetación y Flórula de la Cuenca Extremeña del Guadiana; Diputacion Provincial de Badajoz: Madrid, España, 1964.

9. Tárrega, R.; Luis-Calabuig, E.; Valbuena, L. Eleven years of recovery dynamic after experimental burning in two Cistus communities. Acta Oecol. 2001, 22, 277-283. [CrossRef]

10. Du Plessis, S.P.; Rink, A.; Goodall, V.; Kaplan, H.; Jubase, N.; Van Wyk, E. Assessment and management of the invasive shrub, Cistus ladanifer, in South Africa. S. Afr. J. Bot. 2017, 117, 85-94. [CrossRef]

11. Martin, L.B.; Juhren, M. Cistus and its response to fire. Lasca Leaves 1954, 4, 65-67.

12. Montgomery, K.R.; Strid, T.W. Regeneration of introduced species of Cistus (Cistaceae) after fire in Southern California. Madroño 1976, 23, 417-427.

13. Clemente, A.S.; Rego, F.C.; Correia, O.A. Demographic patterns and productivity of post-fire regeneration of portuguese mediterranean maquis. Int. J. Wildland Fire 1996, 6, 5-12. [CrossRef]

14. Castroviejo, S.; Aedo, C.; Cirujano, S.; Laínz, M.; Montserrat, P.; Morales, R.; Garmendia, F.M.; Navarro, C.; Paiva, J.; Soriano, C. Flora Iberica: Plantas Vasculares de la Península Ibérica e Islas Baleares. Volume III. Plumbaginaceae (Partim)—Capparaceae; Real Jardín Botánico and CSIC: Madrid, Spain, 1993; ISBN 84-00-07375-4. 
15. Corral, R.; Perez-Garcia, F.; Pita, J.M. Seed morphology and histology in four species of Cistus L. (Cistaceae). Phytomorphology 1989, 39, 75-80.

16. Juhren, G. The use of Cistus in erosion control. Lasca Leaves 1956, 6, 26-29.

17. Ching, F.T. Slow burning plant research project. A progress report. Lasca Leaves 1959, 9, 75-80.

18. Knapp, R. Rock roses-Cistus. Components of the shrub vegetation and their usefulness in soil conservation. Lasca Leaves 1962, 12, 77-79.

19. The PLANTS Database. Available online: http://plants.usda.gov (accessed on 1 December 2018).

20. Laure, G.; Oieni, S.; Zinke, P. A burning test on Cistus chaparral in Sicily. Lasca Leaves 1961, 11, 67-72.

21. Bolaños, M.M.; Lopez, E.G. Jarales y Jaras (Cistografia Hispanica); Ediciones Ares: Madrid, Spain, 1949.

22. Corral, R.; Pita, J.M.; Pérez-García, F. Some aspects of seed germination in four species of Cistus L. Seed Sci. Technol. 1990, 18, 321-325.

23. Valbuena, L.; Tárrega, R.; Luis, E. Influence of heat on seed germination of Cistus laurifolius and Cistus ladanifer. Int. J. Wildland Fire 1992, 2, 15-20. [CrossRef]

24. Pérez-Garcia, F. Germination of Cistus ladanifer seeds in relation to parent material. Plant. Ecol. 1997, 133, 57-62. [CrossRef]

25. Ferrandis, P.; Herranz, J.M.; Martínez-Sánchez, J.J. Effect of fire on hard-coated Cistaceae seed banks and its influence on techniques for quantifying seed banks. Plant Ecol. 1999, 144, 103-114. [CrossRef]

26. Chamorro-Moreno, S.; Rosúa-Campos, J.L. The relationships between lengthening capacity of seedlings and the post-fire germinative behaviour of six Cistus species. Rev. Ecol. 2004, 59, 409-424.

27. Margaris, N.S. Adaptive strategies in plants dominating Mediterranean-type ecosystems. In Mediterranean-type Shrublands; Castri, F., Goodal, D.W., Specht, R.L., Eds.; Elsevier: Amsterdam, The Netherlands, 1981; pp. 309-315, ISBN 0-444-41858-X.

28. Vuillemin, J.; Bulard, C. Ecophysiologie de la germination de Cistus albidus L. et Cistus monspeliensis L. Nat. Monspel. Sér. Bot. 1981, 46, 1-11.

29. Baskin, C.C.; Baskin, J.M. Seeds. Ecology, Biogeography, and Evolution of Dormancy and Germination; Academic Press: San Diego, CA, USA, 1998; ISBN 0-12-080260-0.

30. Moreira, B.; Tormo, J.; Estrelles, E.; Pausas, J.G. Disentangling the role of heat and smoke as germination cues in Mediterranean Basin flora. Ann. Bot. 2010, 105, 627-635. [CrossRef]

31. Krollmann, P.; Eich, C.; Gülz, P.-G. Epicuticular waxes of seed coats from species of the genus Cistus L. (Cistaceae). Z. Nat. 1984, 39c, 521-524. [CrossRef]

32. Delgado, J.A.; Serrano, J.M.; López, F.; Acosta, F.J. Seed size and seed germination in the Mediterranean fire-prone shrub Cistus ladanifer. Plant Ecol. 2008, 197, 269-276. [CrossRef]

33. DeBano, L.F.; Dunn, P.H.; Conrad, C.E. Fire's effect on physical and chemical properties of chaparral soils. In Proceedings of the Symposium on the Environmental Consequences of Fire and Fuel Management in Mediterranean Ecosystems, Palo Alto, CA, USA, 1-5 August 1977; USDA Forest Service: Washington, DC, USA, 1977; pp. 65-74.

34. Trabaud, L. Etude du comportement du feu dans la Garrigue de Chêne kermes à partir des temperatures et des vitesses de propagation. Ann. Sci. 1979, 36, 13-38. [CrossRef]

35. Vélez, R. Los incendios forestales en España. Ecología 1990, 1, 213-221.

36. Odion, D.C.; Davis, F.W. Fire, soil heating, and the formation of vegetation patterns in chaparral. Ecol. Monogr. 2000, 70, 149-169. [CrossRef]

37. Baeza, M.J.; Raventós, J.; Escarré, A. Ulex parviflorus germination after experimental burning: Effects of temperature and soil depth. In Fire and Biological Processes; Trabaud, L., Prodon, R., Eds.; Backhuis Publishers: Leiden, The Netherlands, 2002; pp. 83-91, ISBN 90-5782-116-8.

38. Santana, V.M.; Baeza, M.J.; Vallejo, V.R. Fuel structural traits modulating soil temperatures in different species patches of Mediterranean Basin shrublands. Int. J. Wildland Fire 2011, 20, 668-677. [CrossRef]

39. Lutes, D.; Keane, R. FOFEM 6.4. First Order Fire Effects Model; Fire Modeling Institute: Missoula, MT, USA, 2017.

40. Sikkink, P.G.; Lutes, D.C.; Keane, R.E. Field Guide for Identifying Fuel Loading Models; United States Department of Agriculture, Forest Service: Rocky Mountain, BC, USA, 2009.

41. Krollmann, P.; Gülz, P.-G. Composition of seed lipids from species of the genus Cistus L. (Cistaceae). Z. Planzenphysiol. 1983, 110, 469-474. [CrossRef]

42. Parsons, R.F. Incidence and ecology of very fast germination. Seed Sci. Res. 2012, 22, 161-167. [CrossRef] 
43. Parsons, R.F.; Vandelook, F.; Janssens, S.B. Very fast germination: Additional records and relationship to embryo size and phylogeny. Seed Sci. Res. 2014, 24, 159-163. [CrossRef]

44. Limpert, E.; Stahel, W.A.; Abbt, M. Log-normal distributions across the sciences: Keys and clues. BioScience 2001, 51, 341-352. [CrossRef]

45. Auld, T.D.; Ooi, M.K.J. Heat increases germination of water-permeable seeds of obligate-seeding Darwinia species (Myrtaceae). Plant Ecol. 2009, 200, 117-127. [CrossRef]

46. Pereiras, J.; Puentes, M.A.; Casal, M. Efecto de las altas temperaturas sobre la germinacion de las semillas del tojo (Ulex europaeus L.). Studia Oecol. 1985, 6, 125-133.

47. Auld, T.D.; O'Connell, M.A. Predicting patterns of post-fire germination in 35 eastern Australian Fabaceae. Aust. J. Ecol. 1991, 16, 53-70. [CrossRef]

48. Herrero, C.; San Martin, R.; Bravo, F. Effect of heat and ash treatments on germination of Pinus pinaster and Cistus laurifolius. J. Arid Environ. 2007, 70, 540-548. [CrossRef]

49. Bolin, J.F. Heat shock germination responses of three eastern North American temperate species. Castanea 2009, 74, 160-167. [CrossRef]

50. Reyes, O.; Trabaud, L. Germination behaviour of 14 Mediterranean species in relation to fire factors: Smoke and heat. Plant Ecol. 2009, 202, 113-121. [CrossRef]

51. Bradshaw, S.D.; Dixon, K.W.; Hopper, S.D.; Lambers, H.; Turner, S.R. Little evidence for fire-adapted plant traits in Mediterranean climate regions. Trends Plant Sci. 2011, 16, 69-76. [CrossRef] [PubMed]

52. Keeley, J.E.; Pausas, J.G.; Rundel, P.W.; Bond, W.J.; Bradstock, R.A. Fire as an evolutionary pressure shaping plant traits. Trends Plant Sci. 2011, 16, 406-411. [CrossRef] [PubMed]

53. Bradshaw, S.D.; Dixon, K.W.; Hopper, S.D.; Lambers, H.; Turner, S.R. Response to Keely et al.: Fire as an evolutionary pressure shaping plant traits. Trends Plant Sci. 2011, 16, 405. [CrossRef] [PubMed]

54. Jaganathan, G.K. Are wildfires an adapted ecological cue breaking physical dormancy in the Mediterranean basin? Seed Sci. Res. 2015, 25, 120-126. [CrossRef]

55. Stone, E.C.; Juhren, G. The effect of fire on the germination of the seed of Rhus ovata Wats. Am. J. Bot. 1951, 38, 368-372. [CrossRef]

56. Egley, G.H.; Paul, R.N.; Lax, A.R. Seed coat imposed dormancy: Histochemistry of the region controlling onset of water entry into Sida spinosa seeds. Physiol. Plant. 1986, 67, 320-327. [CrossRef]

57. Briggs, C.L.; Morris, E.C.; Ashford, A.E. Investigations into seed dormancy in Grevillea linearifolia, G. buxifolia and G. sericea: Anatomy and histochemistry of the seed coat. Ann. Bot. 2005, 96, 965-980. [CrossRef] [PubMed]

58. Zeng, L.W.; Cocks, P.S.; Kailis, S.G.; Kuo, J. The role of fractures and lipids in the seed coat in the loss of hardseededness of six Mediterranean legume species. J. Agric. Sci. 2005, 143, 43-55. [CrossRef]

59. Briggs, C.L.; Morris, E.C. Seed-coat dormancy in Grevillea linearifolia: Little change in permeability to an apoplastic tracer after treatment with smoke and heat. Ann. Bot. 2008, 101, 623-632. [CrossRef] [PubMed]

60. Egerton-Warburton, L.E. A smoke-induced alteration of the sub-testa cuticle in seeds of the post-fire recruiter, Emmenanthe penduliflora Benth. (Hydrophyllaceae). J. Exp. Bot. 1998, 49, 1317-1327. [CrossRef]

61. Keeley, J.E.; Fotheringham, C.J. Mechanisms of smoke-induced seed germination in a post-fire chaparral annual. J. Ecol. 1998, 86, 27-36. [CrossRef]

62. Trabaud, L.; Oustric, J. Heat requirements for seed germination of three Cistus species in the garrigue of southern France. Flora 1989, 183, 321-325. [CrossRef]

63. Roy, J.; Sonié, L. Germination and population dynamics of Cistus species in relation to fire. J. Appl. Ecol. 1992, 29, 647-655. [CrossRef]

64. Pérez-Fernández, M.A.; Rodríguez-Echeverría, S. Effect of smoke, charred wood, and nitrogen compounds on seed germination of ten species from woodland in central-western Spain. J. Chem. Ecol. 2003, 29, $237-251$. [CrossRef] [PubMed]

65. Bansal, R.P.; Bhati, P.R.; Sen, D.N. Differential specificity in water imbibition of Indian arid zone seeds. Biol. Plant. 1980, 22, 327-331. [CrossRef]

66. Larson, M.M. The effect soaking pea seeds with or without seedcoats has on seedling growth. Plant Physiol. 1968, 43, 255-259. [CrossRef] [PubMed]

67. Ribeiro, R.C.; Oliveira, D.M.T.; Oliveira, F.A.O. A new seed coat water-impermeability mechanism in Chaetostoma armatum (Melastomataceae): Evolutionary and biogeographical implications of physiophysical dormancy. Seed Sci. Res. 2015, 25, 194-202. [CrossRef] 
68. Talavera, S.; Gibbs, P.E.; Herrera, J. Reproductive biology of Cistus ladanifer (Cistaceae). Plant Syst. Evol. 1993, 186, 123-134. [CrossRef]

69. Alonso, I.; Luis, E.; Tárrega, R. First phases of regeneration of Cistus laurifolius and Cistus ladanifer after burning and cutting in experimental plots. Int. J. Wildland Fire 1992, 2, 7-14. [CrossRef]

70. Alías, J.C.; Sosa, T.; Escudero, J.C.; Chaves, N. Autotoxicity against germination and seedling emergence in Cistus ladanifer L. Plant Soil 2006, 282, 327-332. [CrossRef]

71. Traba, J.; Azcárate, F.M.; Peco, B. From what depth do seeds emerge? A soil seed bank experiment with Mediterranean grassland species. Seed Sci. Res. 2004, 14, 297-303. [CrossRef]

72. Luna, B.; Moreno, J.M. Light and nitrate effects on seed germination of Mediterranean plant species of several functional groups. Plant Ecol. 2009, 203, 123-135. [CrossRef]

73. Bodí, M.B.; Cerdà, A.; Mataix-Solera, J.; Doerr, S.H. Efectos de los incendios forestales en la vegetación y el suelo en la cuenca mediterránea: Revisión bibliográfica. Bol. Asoc. Geógr. Esp. 2012, 58, 33-55. [CrossRef]

74. Bradstock, R.A.; Auld, T.D. Soil temperatures during experimental bushfires in relation to fire intensity: Consequences for legume germination and fire management in south-eastern Australia. J. Appl. Ecol. 1995, 32, 76-84. [CrossRef]

75. Thanos, C.A. Fire effects on forest vegetation, the case of Mediterranean pine forests in Greece. In Wildfire Management; Eftichidis, G., Balabanis, P., Ghazi, A., Eds.; Algosystems \& European Comission DGXII: Athens, Greece, 1999; pp. 323-334.

76. Agencia Estatal de Meteorología, Ministerio de Medio Ambiente y Medio Rural y Marino; Instituto de Meteorologia de Portugal. Atlas Climático Ibérico, Temperatura del Aire y Precipitación (1971-2000)/Atlas Climático Ibérico, Temperatura do Ar e Precipitação (1971-2000)/Iberian Climate Atlas, Air Temperature and Precipitation (1971-2000); Agencia Estatal de Meteorología, Ministerio de Medio Ambiente y Medio Rural y Marino: Madrid, Spain; Instituto de Meteorologia de Portugal: Lisboa, Portugal, 2011; ISBN 978-84-7837-079-5.

77. Rietveld, W.J. Phytotoxic Grass Residues Reduce Germination and Initial Root Growth of Ponderosa Pine; United States Department of Agriculture Forest Service: Fort Collins, CO, USA, 1975.

78. Dias, L.S. Describing phytotoxic effects on cumulative germination. J. Chem. Ecol. 2001, 27, 411-418. [CrossRef] [PubMed]

79. Spólnik, P.; Stopa, B.; Piekarska, B.; Jagusiak, A.; Konieczny, L.; Rybarska, J.; Król, M.; Roterman, I.; Urbanowicz, B.; Zieba-Palus, J. The use of rigid, fibrillar Congo red nanostructures for scaffolding protein assemblies and inducing the formation of amyloid-like arrangement of molecules. Chem. Biol. Drug Des. 2007, 70, 491-501. [CrossRef] [PubMed]

80. Al-Thabaiti, S.A.; Aazam, E.S.; Khan, Z.; Bashir, O. Aggregation of Congo red with surfactants and Ag-nanoparticles in an aqueous solution. Spectrochim. Acta Part A Mol. Biomol. Spectrosc. 2016, 156, 28-35. [CrossRef] [PubMed]

81. Bond, W.J.; Honig, M.; Maze, K.E. Seed size and seedling emergence: An allometric relationship and some ecological implications. Oecologia 1999, 120, 132-136. [CrossRef] [PubMed]

82. Luna, B.; Chamorro, D. Germination sensitivity to water stress of eight Cistaceae species from the Western Mediterranean. Seed Sci. Res. 2016, 26, 101-110. [CrossRef]

83. Box, G.E.P.; Cox, D.R. An analysis of transformations. J. R. Stat. Soc. B 1964, 26, 211-252. [CrossRef]

84. Chew, V. Comparing means: A compendium. HortScience 1976, 11, 348-357.

85. Ury, H.K. A comparison of four procedures for multiple comparisons among means (pairwise contrasts) for arbitrary sample sizes. Technometrics 1976, 18, 89-97. [CrossRef]

86. Draper, N.R.; Smith, H. Applied Regression Analysis, 3rd ed.; John Wiley: New York, NY, USA, 1998; ISBN 0-471-17082-8.

87. Weibull, W. A statistical distribution function of wide applicability. J. Appl. Mech. 1951, 18, $293-297$.

88. Marquardt, D.W. An algorithm for least-squares estimation of nonlinear parameters. J. Soc. Ind. Appl. Math. 1963, 11, 431-441. [CrossRef]

89. Dubey, S.D. Normal and Weibull distributions. Nav. Res. Logist. Q. 1967, 14, 69-79. [CrossRef]

90. Bonner, F.T.; Dell, T.R. The Weibull function: A new method of comparing seed vigor. J. Seed Technol. 1976, 1, 96-103. 
91. Dias, A.S.; Pereira, I.P.; Dias, L.S. Investigating and modeling the combined effects of $\mathrm{pH}$ and osmotic pressure on seed germination for use in phytoactivity and allelopathic research. Plant Biosyst. 2017, 151, 657-664. [CrossRef]

92. Hazony, Y. Algorithms for parallel processing: Curve and surface definition with $Q$-splines. Comput. Gr. 1979, 4, 165-176. [CrossRef] 